by H.S.Saini ${ }^{1}$, Apurva Alok ${ }^{2}$, N.C. Pant ${ }^{2}$

\title{
The Lost Saraswati River of Northwestern Indian Plains: Status and way forward
}

\author{
1. Director (Retd.), Geological Survey of India. Faridabad, INDIA \\ 2. Dept of Geology, University of Delhi, Delhi, INDIA.
}

(Received : 4/1/2019; Revised accepted : 21/9/2019)

https://doi.org/10.18814/epiiugs/2020/020034

Buried course of the desiccated river Saraswati/ Ghagghar-Hakara from Himalayan front to Arabian Sea through the plains of NW India has been in discussion and scientific investigations since 140 years due to its importance in societal evolution and drainage disorganization. Its plains were inhabited by the Harappan/ Indus civilization (7000-1200BC) which collapsed around 4-3 ka BP. Views, both, in favor and against a relation between collapse of civilization and drying up of the Saraswati river exist. The palaeocourse of this river, causes and timing of its drying and reasons of civilization collapse still elude consensus. A large amount of new data generated in last two decades on surface, subsurface and chronological aspects of the Holocene deposits and archeology along the path of the Saraswati river has enhanced our understanding but the problem of defining its evolution through geological time is very complex.

In this paper we critically examine the views on the link of the Saraswati paleochannel with the Sutlej towards west and Yamuna towards east as source for the perennial water supply. We also discuss the role of climate change and evaluate the role of active faults (Himalayan Frontal Trust and tear faults), basement structure (DelhiSargodha Ridge) and seismicity of the Haryana plains in context of the drainage reorganization as a possible cause of the drying up of the river. Systematic mapping of the entire palaeochannel course with generation of sedimentological and chronological data for the gap areas is suggested for understanding the evolution and demise of the Saraswati river.

\section{Introduction}

The Saraswati, a mythological Himalayan river, is believed to have existed in the NW plains of India through the states of Punjab, Haryana, Rajasthan and Gujarat and parts of modern Pakistan during the Vedic period which supported and sustained a big Vedic / Indus / Harrapan civilization on its plains (Fig.1). Existence of the Saraswati River is one of the oldest debated issues in Indian Geology and archeology. The "lost river Saraswati” was first proposed by Oldham (1886) who traced a dry river bed in Rajasthan to the coast of Gujarat. The course showed several tributaries in Punjab plains between modern Ghagghar and Sutlej rivers which joined to form the main Saraswati river in northern Rajasthan. Similar course and few landforms of dried up channels were observed in Punjab plains by Oldham (1893) and Stein (1942). About a century later, Indian workers picked up the Saraswati palaeodrainage research and reported a number of palaeocourses of Saraswati river using remote sensing imagery (Wilhelmy, 1999; Yashpal et al., 1980; Sood and Sahai, 1983; Ghose et al., 1979; Bakliwal et al., 1998; Sahai, 1999; Kar, 1999;Roy and Jhakhr,2001; Rajawat et al., 2003; Gupta et al., 2004; Radhakrishna and Merh, 1999; Valdiya, 1996, 2002, 2013, 2016; Bhadra et al., 2009). Many of these studies also drew support from the ancient Hindu text Rigveda in which existence of the Saraswati river is frequently mentioned as a river that drained northwestern India during the Vedic period and sustained the Indus Civilization in its basin from Himalayan front to Gujarat coast (Sharma, 1974; Kalyanaraman, 2008).

This far, the research lacked field investigations and ground level validations of the palaeocourses on imagery. However, a strong global interest of archeological and geological researchers developed in the beginning of $21^{\text {st }}$ century due its implication on (i) climate-river channel interactions and (ii) climate-society and landscape interaction. Further the availability of modern chronological, chemical (including isotope) and high resolution remote sensing data and processing techniques provided a renewed impetus to the study of the "Lost River Saraswati”. The palaeodrainage maps associated with Sarswati river were upgraded and refined (Mehdi et al., 2016; Srivastava et al., 2014; Singh et al., 2017; Orengo et al., 2017), chronology of fluvial and aeolian architecture of parts of Saraswati plains developed (Saini et al., 2009; Saini and Mujtaba, 2010; Clift et al., 2012; Dixit et al., 2014, 2018; Singh et al., 2017) and geochemical finger printing of provenance and climate-tectonic correlations worked out (Tripathi et al., 2004;Clift et al., 2012, 2018). The isotopic signatures from buried sediments of the Saraswati like river flowing parallel to the Indus river has been traced from Punjab to Great Rann of Kutch 


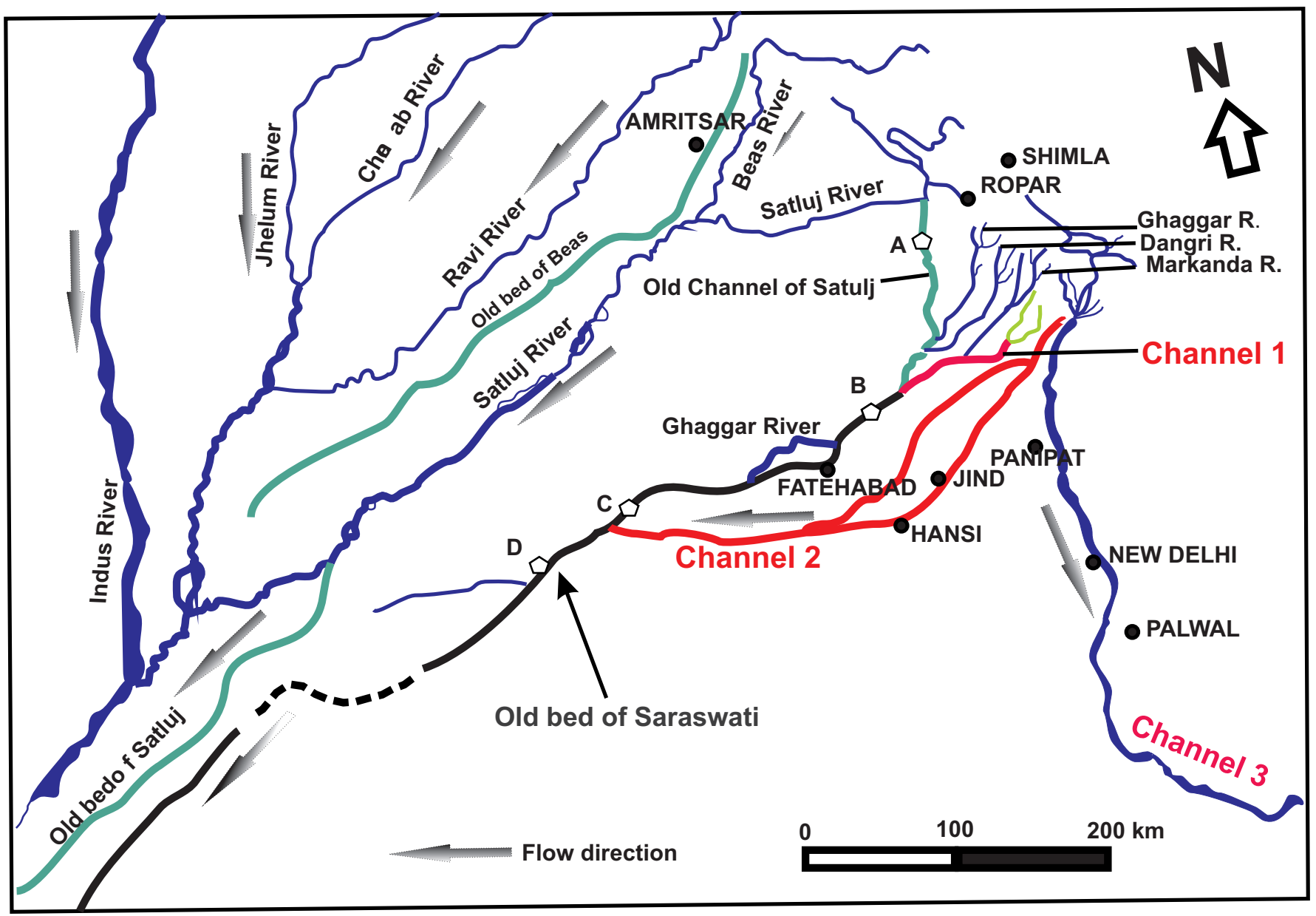

Figure 1. Drainage map of northwestern India showing old bed of Saraswati river which is largely occupied by modern Ghagghar River except a $35 \mathrm{~km}$ loop which flows north of the palaeochannel near Fatehabad. The old connections with Satluj River and Yamuna river are also shown (After Yashpal, et al, 1980). Point A to D are the locations of OSL chronology indicating cessation of river flows.

(Gujarat) through Rajasthan (Singh et al., 2016; Khonde et al., 2017).Shallow subsurface studies brought out the buried fluvioaeolian landscape and its relation with the Saraswati River (Saini et al., 2009;Kshetrimayum and Bajpai, 2012;Sinha et al., 2013).

Similarly the dynamics of distribution, migration and dispersal of Harappan/ Indus civilization vis-à-vis its association with the Saraswati river and the climate change were also vigorously pursued (Mughal, 1997; Kenoyer, 1998; Possehl, 2002; Madella and Fuller, 2006; Giosen et al., 2012). The Indus was a large Bronze age civilization of the old world scattered in NW India and Cholistan of Pakistan under varied physiography and climate. Its urban phase was the best flourished period ca. 2600-1900 BC (Kenoyer 1998; Lal, 2002; Lawler, 2008; Chakrabarti and Saini, 2009) which declined for reasons still not well known.

Most of these studies are focused on specific segments of the paleochannel course leaving large gaps in between its exit point at Himalayan front and the Arabian sea. The hydrology and timings of flow and drying/ disappearance, and the reason thereof also require in depth investigation. In following we attempt to discuss some of these questions.

In spite of similar palaeocourses of the Saraswati river (also referred as Ghagghar-Hakara) proposed by remote sensing techniques in Rajasthan and Gujarat, divergent views still persist on its upstream continuity in the Himalayan piedmont for a perennial water source and the timing of river drying (Yashpal et al., 1980; Sood and Sahai, 1983; Ghose et al., 1979; Sahai, 1999; Kar, 1999; Gupta et al., 2004; Valdiya, 1996, 2002). Whether today's Ghagghar river was Saraswati (Valdiya 1996; Gupta et al., 2004; Sharma, 2008) or a channel of Sutlej river drained into it (Oldham 1893; Naruse, 1974, 1985; Singh et al., 2016) or the Yamuna river was tributary to it (Clift 2012; Clift and Giosan, 2018) are some of the hypotheses explored so far. If not these, then was the Saraswati an independent river emptying in the Arabain Sea (Khonde et al., 2017). Broadly the three models exist as (i) Saraswati was a glacial fed river which disappeared due to tectonic and climatic reasons (Valdiya, 2002, 2013); (ii) both Sutlej and Yamuna drained through this region and Yamuna migrated towards east between 49-10 ka (Clift et al., 2012) and that (iii) only monsoon fed rivers were active in the region during Holocene (Tripathi et al., 2004; Giosan et al., 2012). Though specific studies have given a good insight on the above aspects but not comprehensively accommodated the role of tectonic, geologic, geomorphic and climatic setting along the entire course of the river. This is due to the paucity of the subsurface geological data and anthropogenic modifications of the original landscape.

In all these studies, Quaternary alluvial plains of Punjab and Haryana, south of Himalayan front, constitute the most critical sector for the Saraswati river research as it has still preserves some good archives of the past alluvial landforms and is not affected by massive 
desertification like downstream reaches of the Saraswati. The area has humid climate near Himalaya (1000mm annual precipitation) that southwards grades into semiarid precipitation in NW Haryana (600-400mm) and arid conditions (300mm) in the northern part of Rajasthan. The effect of climate is visible on the modern drainage originating in humid part which disappears in the semiarid and arid parts after traversing 40-80 km downstream. In the arid region alluvial landforms have been masked by younger aeolian deposits barring few imprints in northern Rajasthan mainly between Hanumangarh and Anupgarh (Rydh, 1958).

\section{Geomorphologic and Geologic setting}

Eastern part of the Indus plains, south of the Himalayan front, in Haryana and Punjab show active as well as buried palaeochannels (Fig.2). On ground, the latter can be identified by high moisture in soil, silt-clay lithology, and fresh groundwater and at places by subtle depression (Saini and Mujtaba, 2010). From north to south, these plains can be broadly demarcated in three geomorphic units, namely, piedmont plain, central alluvial plain and the Thar fringe (Anand and Kazim, 1992; Thussu, 1999, 2006; Srivastava et al., 2006, 2014).

The piedmont plain is $20-30 \mathrm{~km}$ wide steep gradient zone between 350 and $300 \mathrm{~m}$ above sea level. Unlike the gravelly piedmont of Ganga basin (Kumar, 2005), it is composed of argillaceous sediments with layers and lenses of gravels and grey sands (Shukla et al., 2014). Two perennial, glacial fed Himalayan Rivers, namely, the Sutlej in the west and the Yamuna in the east are separated $150 \mathrm{kms}$ at their exits from the Himalaya. The Sutlej river flows southwesterly and the Yamuna southeasterly. Both have well defined valleys flanked by 2$5 \mathrm{~m}$ high terraces (Kumar, 2005; Saini and Mujtaba, 2010). The Ghagghar river originates in the outer Siwalik ranges near Morni Hills and flows south-southeasterly in the interfluve zone of the Sutlej and the Yamuna rivers. Besides, a number of seasonal, monsoon and

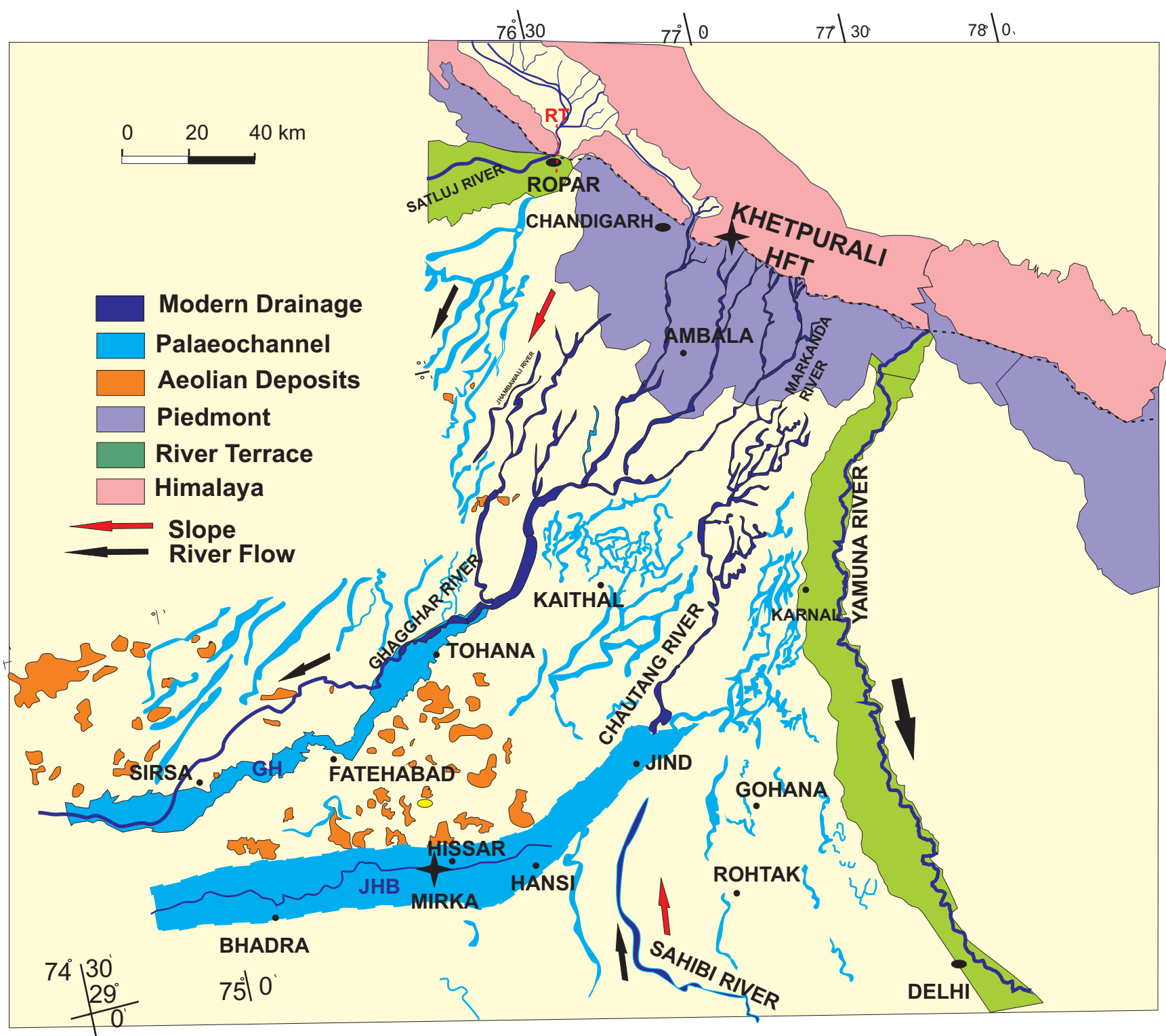

Figure 2. Geomoprhological map of a part of the piedmont and central alluvial plain between Satluj and Yamuna rivers showing plaeo and modern drainage. GH is Ghagghar-Hakara palaeochannel, JHB is Older palaeochannel along Chautang river. (Base map after Anand and Kazim, 1992). 
groundwater fed drainages such as Dangri, Markanda and Chautang also originate from the piedmont zone. These rivers transport pebbles for about $30 \mathrm{~km}$ length of river up to the limit of piedmont zone. Except, Chautang river, all other drainage join the Ghagghar river at a maximum distance of $180 \mathrm{~km}$ south of the Himalayan front. Most of them are entrenched streams with sub-dendritic to sub parallel drainage patterns. Palaeochannel impressions are sparse in the piedmont zone.

The central alluvial plain is a low relief surface with imperceptible southwesterly slope and dotted with paleo and buried channels, lakes and depressions, aeolian mound etc. An interesting feature of this zone is the existence of a subtle east-west saucer like depression along the Rohtak-Maham-Hansi axis which is prone to flooding following heavy rains. The area south of this axis has a northerly slope with two ephemeral northerly flowing drainage of the Dohan and the Sahibi rivers (Fig.2).

Geologically, the piedmont and central alluvial plain are devoid of rock exposures. In central alluvial plain, NNE-SSE trending outcrops of Delhi Supergroup rocks terminate along WNW-SES Delhi-Tosham line and becomes subterranean northward (Thussu, 1995). The bedrocks lay around 200 to $>400 \mathrm{~m}$ deep below the Quaternary overburden and are affected by hidden faults (Thussu, 1995; Saini and Anand, 1996).

\section{Palaeochannels and the Saraswati river}

Nearly all studies, so far, agree on the course of Ghagghar-Hakara palaeochannel from downstream reaches to Tohana -Satrana in upstream (GH in Fig.2). Beyond this, there are three views on its feeder Himalayan connection, i.e., through Sutlej or Yamuna or Ghagghar?

\section{The Sutlej and the Ghaghara-Hakara Link}

This view has grown stronger in recent studies which suggest that an avulsed channel of the Sutlej river joined the Ghagghar-Hakara river north of Tohana and that the latter was actually a former course of the Sutlej which subsequently dried up (Singh et al., 2016). Studies tend to point out that desiccation of the Ghagghar-Hakara was a long process of few thousand years during which different segments of river dried up at different times. It appears that the flow of water first ceased in the avulsed channel of the Sutlej during 15-12 ka (A in Fig.1). The flow dried-up around 8 ka near its confluence with Ghagghar-Hakara, (B in Fig.1) and at about 12 ka near Kalibanga,150 km downstream of the confluence C in Fig.1 (Singh et al.,2016). Further, about $200 \mathrm{~km}$ downstream of Kalibanga, the channel flow near Fort Abbas, Chak and Marot in Pakistan stopped between 7.3 and 5 ka (Clift et al., 2012; D in Fig.1). Continuity of river till around 10 ka is also recorded in Great Rann of Kutch, just before its entry in the Arabian Sea, (Khonde et al. 2017). However, sediments characters in the palaeochannel near Fatehabad indicate that river was active until around $4.3 \mathrm{ka}$ (Saini and Mujtaba, 2010).

A missing link in the Sutlej connection is the absence of surface evidence of the palaeochannel from its mountain exit to its proposed confluence with Ghagghar-Hakara channel. The valley of modern Sutlej is 2-5m deep and 10-25 km wide (25 km wide between Firozpur and Faridkot (Saini and Mujtaba, 2003). Considering that the avulsed channel which disappeared 11.6 \pm 0.4 ka ago (Singh et al., 2016) was weaker than the main Sutlej river, it is unlikely that its channel completely perished leaving no scar of westerly shift. Incidentally a number of NNE-SSW trending palaeochannels have been identified in the area between Ghagghar and Sutlej rivers which appear to join the Ghagghar at different locations downstream of Tohana (Ananad and Kazim, 1992). Thus in spite of new data, this view needs further corroborative evidence from surface and subsurface across the avulsed Sutlej channel to establish the Sutlej- Ghagghar-Hakara linkage.

\section{The Yamuna- Ghagghar-Hakara link}

Yashpal et al. (1980) identified three channels of Yamuna (Y1, Y2, and Y3, Fig.1) in which the northern most, Y1, joined Ghagghar near Satrana while Y2 and Y3 joined Ghagghar-Hakara near Suratgarh in Rajasthan through Jind-Hissar-Bhadra axis. Some of these palaeocourses were verified by Mehadi et al. ( 2016) and also mapped by ground survey as a $2 \mathrm{~km}$ wide silt-clayey surface extending east and west of Hissar (Saini and Mujtaba, 2004) with no apparent surface depression (JHB in Fig.2). The modern Chautang River descending from piedmont zone joins this course and disappears near Jind (Fig.2). The Hansi - Jind stretch of this palaeocourse is a well-known flood prone zone. According to Clift et al. (2012) the Yamuna River flowed eastward to join the Ghagghar-Hakara probably through JHB palaeocourse some $49 \mathrm{ka}$ ago. This course of Yamuna shifted eastward somewhere between $49 \mathrm{ka}$ and $10 \mathrm{ka}$. The palaeocourse JHB is occupied by a number of sand dunes on surface whose chronology give us the upper time limit of the river disappearance. OSL quartz dating of pits and well sections near Mirka, Ganguwana and Rawalwas (Fig.2) near Hissar showed that fluvial activities, in this palaeocourse presently buried at six meter depth, ceased between 26 and 18 ka and was followed by dune deposition between ca. 17-12 ka (Saini and Mujtaba, 2012). This palaeocourse, thus, appears very old and does not support the premises that Saraswati/ Ghagghar-Hakara drew water from Yamuna during the period of Indus civilization, though minor fluvial activity at some places is indicated at around $8 \mathrm{ka}$ (Saini and Mujtaba, 2012).

\section{The Ghagghar and Ghagghar-Hakara link}

The third contention of modern Ghagghar being the paleo Saraswati has many support and critique. Near the Himalayan exit, in piedmont zone, the Ghagghar is a robust river making wide channel with channel bars cut terraces (Fig.3A). Downstream it is an entrenched, locally meandering river with gradually narrowing channel which reduces to $<50 \mathrm{~m}$ in some stretches between Tohana and Sirsa (Fig.3B). The Ghagghar-Hakara paleochannel appears near Tohana in Haryana as a low lying, flood prone, high moisture zone with narrow, rudimentary, ephemeral courses. It extends southwestward as 2-7 km wide channelized zone, most conspicuous near Fatehabad and makes $\sim 5 \mathrm{~m}$ high scarp on its southern bank near Hoshanga where the northern bank, however, is not discernable (Saini and Mujtaba, 2010). It is further characterized by absence of aeolian deposits, presence of reddish clay on surface and fresh quality of ground water. West of Fatehabad, the depression gradually shallows down and attains the level of adjacent uplands, but the reddish clayey surface and its flood prone nature continues further west. The Ghagghar river occupies this depression southwest of Sirsa from where 

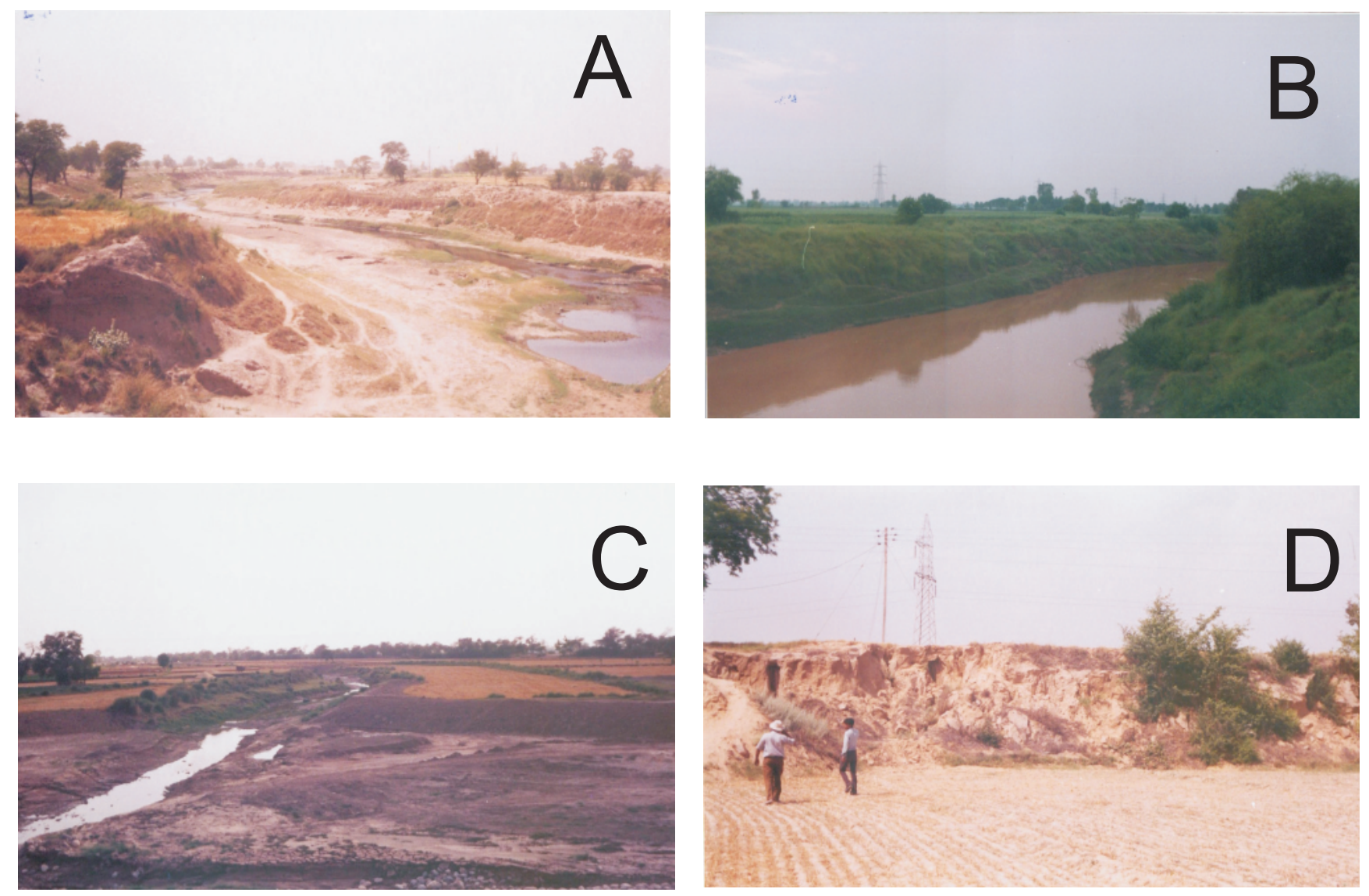

Figure 3. Different forms of Ghagghar River. (A). Deep and wide channel in the Piedmont zone with isolated terraces. (B). Narrow channel between Toahana and Sirsa when it flows independent of the Ghagghar-Hakara palaeochannel. In this zone the channel shows two prominent lateral shifts. (C). Shallow and narrow channel downstream of Sirsa when Ghagghar flows through the palaeochannel zone. (D). A sandy scarp marking the northern palaeobank of Ghaggahr downstream of Ottu.

it flows as a small stream with wide flood plain (Fig.3C) and at places with 3-5m high paleobank (Fig.3D). The Ghagghar river, even though disappears in Rajasthan, but its palaeocoaurse continues up to Anupgarh (DG, ASI map in Rydh, 1958) with an average width of 5 km (Maemoku et al., 2012).

Near Tohana, Ghagghar occupies the course of palaeochannel for a short distance and then diverts and flows for about $35 \mathrm{~km}$ as an independent river north of palaeochannel. Further downstream, southeast of Sirsa, it re-occupies the palaeochannel zone which is flanked by low lying Pre and Harrapan mounds on the periphery. It is shown that fluvial activity in the palaeochannel was active around \%-4 ka and even before and diminished at $\sim 4$ and 3.4 ka (Saini and Mujtaba, 2010). The major dune accumulation in this region, during 18-12 ka (Saini and Mujtaba, 2012) has not affected the palaeochannel because it was a wet surface and prevented the dunes to be formed in its channel.

In the absence of a perennial catchment of water, it is unlikely to consider the Ghagghar river as the predecessor of the Lost River Saraswati. The Ghagghar has a small monsoon fed catchment of 570 sq km spread in 10 sub-basins. New studies show that Ghagghar is also an old river which passes through the gravelly terraces deposited during a long period of about 156 to 56 ka in upper reaches, 17-15 ka in piedmont zone and 7-1.8 ka just downstream of piedmont zone (Shukla et al., 2014). During non-monsoon period, its lean flow is maintained by groundwater hardly sufficient to keep the river wet downstream of Ottu. Therefore, unless it had a connectivity with any
Himalayan river, it is not possible to accept it as the Vedic Saraswati river reaching Arabian sea

\section{Societal Evolution and the Saraswati River}

The Indus-Saraswati river plains in northwestern India and adjoining regions were inhabited by human communities from Neolithic to fourth millennium historic period but are best known for the Old World largest Harrapan (Indus) civilization that thrived during 5.7-3.3 ka (Kenoyer, 1998; Dikshit, 2012) or 9-2.5 ka (Possehl, 2002) on the flood and alluvial plains, in desert and alluvial fans (Petrie et al., 2016). Even though the Saraswati plains experienced arid and semi-arid climate as compared to the humid climate of the Ganga plains, the early human societies favored the former probably due to its low forested surface. The Pre-Harrapan, also known as Hakara, was a village based culture scattered in Cholistan desert and also along palaeochannel of the Saraswati in Hissar and Fatehabad (Sarkar et al., 2016). The mature Harrapan (2600-1900 BC) was a highly evolved urban phase with five major cities of Mojenjo-daro, Harappa, Rakhigarhi and Dholavira each with large village hinterlands (Kenoyer, 2008; Petrie, 2013). Agriculture and trading were dominant occupations. It is suggested that the perennial supply of water by Saraswati River sustained this society. Interestingly the society collapsed when it was well developed and transformed in a village 
based society which is known as the late Harappan phase. The density of dwelling units reduced in the western and central part of basin and increased towards east and north (Fig.4) (Allchin, 1995; Petrie et al, 2016).

Both social and natural reasons have been cited for this decline. Archeologists believe that loss of river flow led to migration of people towards north (Mishra, 1984; Moghul, 1997; Possehl, 2002). Geological studies also show reduced summer monsoon rains during 4.1 and $4.0 \mathrm{ka}$ BP starved the river flow and affected the agriculture production forcing the dispersal of urban society (Clift and Plumb, 2008;Giosan et al., 2012; Staubwasser and Weiss, 2006; Dixit et al., 2014, 2018). The northerly shift was influenced by the availability of regular flooding due to stronger winter monsoon in the Himalayan foothill region (Wright et al., 2008; Petrie et al., 2017; Giosan et al., 2018). In view of this it is difficult to suggest a direct dependence of Indus society on the Saraswati River which considerably dried up much before the establishment of urban phase of Indus civilization (Singh et al., 2017; Giosan et al., 2018; Clift and Giosan, 2018).

\section{Discussions}

The drying up of the Saraswati river is attributed to monsoon weakening (Tripathi et al., 2004; Giosan et al., 2012; Dixit et al., 2014, 2018) and tectonic shifts (Valdiya,1996). New data from lake, aeolian, fluvial deposits utilizing OSL, AMS ${ }^{14} \mathrm{C}$ dating and isotopic $\delta^{18} \mathrm{O}$ from ostracodes, gastropods and carbonates along with the geomorphological studies has helped in developing high resolution climate chronology. It shows prevalence of dry condition around $5.3 \mathrm{ka}$ BP in the Thar desert (Enzel et al., 1999), at $4.1 \mathrm{ka}$ on its northern margin around lake Karasandi and the eastern margin around Kotla Dahar (Dixit et al., 2014, 2018). The marine record from the Arabian sea (Staubwasser, 2003) and a speleothem from northeast India (Berkelhammer, 2013) also suggest decreased summer monsoon at $\sim 4.1$ ka BP. Incidentally this time period coincides with the deurbanization phase of the Harappan civilization when people started deserting their dwellings. However, the fossil bone biosparite from Birhana near the Ghagghar-Hakara paleochannel north of Fatehabad suggested an early decline of monsoon at around 7.0 ka BP (Sarkar et al., 2016).

Geological archives of last fluvial activity, buried at 8- 6m depth in NW Haryana plains, indicate strong monsoon rains during 34-18 ka (Saini and Mujtaba 2012; Shukla et al., 2014) while flow of the Ghagghar-Hakara palaeochannel ceased much later during 12-4 ka. The earliest drying of river flow is indicated at around 12 ka near the mountain exit and in middle reach of the Ghagghar-Hakara palaeochannel near Kalibanga (Singh et al., 2016), 10 ka in lowermost reach in Ran of Kutch (Khonde et al., 2017), 5 ka near Fort Abbas (Clift et al., 2012), 8 ka near Sutlej-Ghagghar confluence (Singh et al., 2016) and 4.3 ka near Fatehabad (Saini and Mujtaba, 2010; A, B, C, D, E in Fig.1).

In addition to fluvial data, higher monsoonal rain during MidHolocene is also evidenced by a lake phase (Saini et al., 2005) which led to the precipitation of $1.5 \mathrm{~m}$ thick lenses of limestone during c.5363 \pm 110 and 3640 yr BP (Bhatia and Singh, 1988) in Haryana plains and $2 \mathrm{~m}$ thick gypsum lenses during about 7.6-4.4 ka in NE Thar fringe (Dixit et al., 2018). This phase was able to sustain a large number of lakes in sandy landscape of northern Rajasthan and also the Ghagghar-Hakara river until ca. 4.1 ka BP when aridity increased and rainfall decreased. The increased aridity resulted in the deposition of sand dune during 3.4-1.8 ka BP near Rohtak and Gurgaon (Saini and Mujtaba, 2010). It indicates that higher monsoon rains during Mid-Holocene was certainly a factor in sustaining the Harappans and the Saraswati River at least in the northern Rajasthan, western Haryana and Punjab.

However, regional studies along the Saraswati palaeocourse show that decreasing flow of the Saraswati river started much earlier than

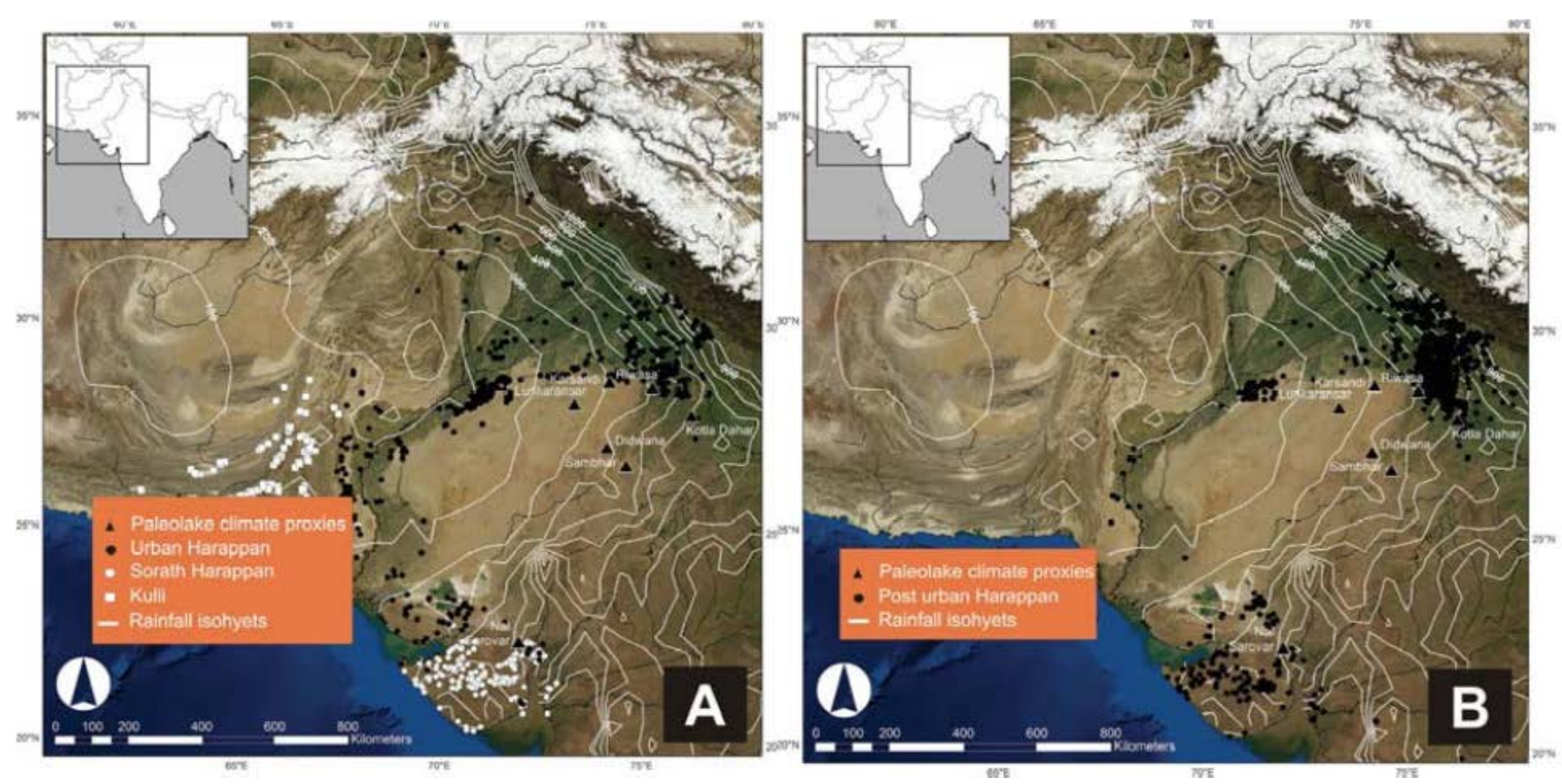

Figure 4. Distribution of archeological sites during Mature Harappan (A) and late Harrapan (B) in northwestern India and adjoining regions. Heavy concentration of sites in northern part during late Harappan is due to migration of people after the disintegration of mature Harrapan phase. Average Isohytes of 1900-2008 period are also shown (After Petrie et al., 2017). 
the 4.1 ka climatic deterioration. This could have triggered the abandonment of the Harappan urban centers but not the drying of the Saraswati River in its entity. At the most it could have substantially reduced the water flow of already weakened river.

\section{Tectonics}

In spite of overwhelming data favoring climate change, it is difficult to comprehend that a large river traversing different climatic regions could have been made defunct by increased aridity. If so, then aridity should have also affected the flow of other nearby rivers namely the Sutlej in west and the Yamuna in east. Therefore, it will be appropriate to look at other causative reason i.e., the recent tectonic disturbances in the region. The neotectonism is less explored aspect

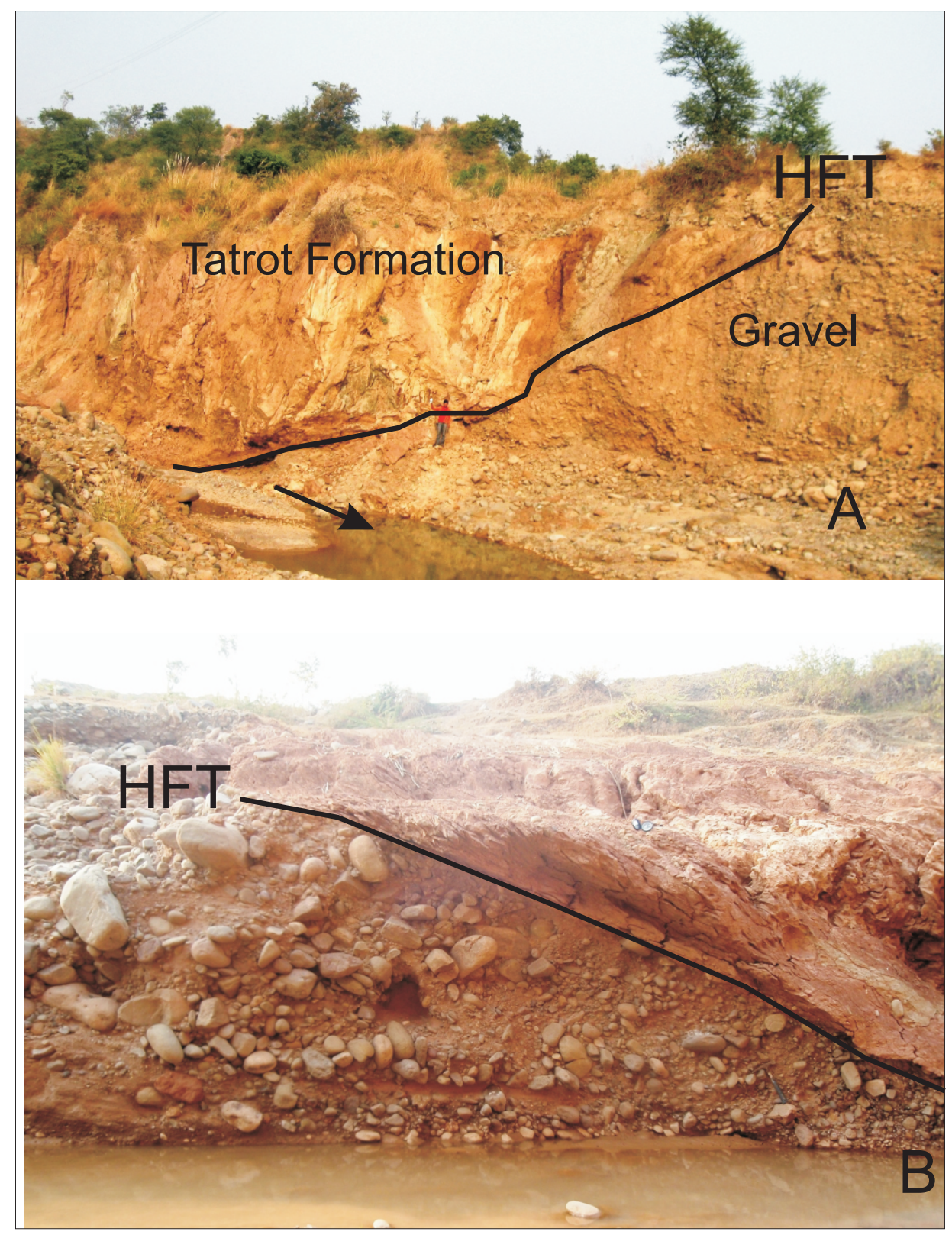

Figure 5. Exposure of Himalayan Frontal Thrust (HFT) at the mountain exit of a drainage at Khetpurali village in Panchkula district Haryana. (A). The Holocene piedmont gravel beds overridden by Middle Siwalik rocks on the right bank. (B.) At the right bank the under-thrusted gravel showing rotations below the HFT. in the drainage disorganization (e.g. Sinha et al., 2013) though it has shown to be an important factor in tectonically active arid domains (e.g. Lal et al., 2018). An active and nearby source of disturbance could be the Himalayan Frontal Thrust (HFT) which separates the Quaternary Indo-Gangetic alluvial basin from the Tertiary Himalayan mountain ranges along its E-W length and represents a regional detachment plain along which Indian plate is sliding below the Himalaya (Nakata, 1972; Valdiya, 2003; Thakur, 2013). It has displaced several Quaternary landforms and modified drainage lines (Nakata, 1989; Mallik et al., 2003;Srivastava et al., 2016). Its last surface rapture has been dated between 1404 - 1422 A.D. with a coseismic slip varying between $~ 18$ - $26 \mathrm{~m}$ at several locations of the exposures (Kumar, 2005). It is mostly a hidden feature but recently many exposures have been mapped. One such exposure is recorded at the Khetpurali and Dulupur villages (Survey of India Toposheet nos 53B/14 and 53F/2) in Panchkula district, Haryana where the Tatrot Formation of Upper Siwalik rocks override the river terrace gravels (Kumar et al., 2012; Fig.5). The thrust dips northerly with 300 m wide crushed zone. The underthrusted gravels also show warping and dragging. Such exposures suggest that the HFT has been active during Holocene and thus compressional rising of the Siwalik ranges must have had a bearing on the flow and alignment of drainage south of it. The Holocene activities of faults like Ghagghar fault, Sirsa -Jhajra Fault (SJF), Pinjor Garden faults, Ropar tear, Kala Amb tear, Yamuna tear and others in the outer Siwalik belt become critical to understand their influence on drainage and landscape.

In addition to the active faults, the Pre-Quaternary basement under the plains of Haryana-Punjab is marked by irregularities of basement ridges and depressions (Wadia, 1978). The basement configuration below Quaternary overburden worked out from the exploratory borehole lithologs of Central Groundwater Water Board and Geological Survey of India drilled in NW Haryana and adjoining Punjab plains indicated the presence of bedrock between 200 to $>400$ meter depth and this further deepens to few kilometer. Presence of Delhi-Sargodha Ridge (DSR) trending NW-SE is located below mean sea level ( -300m) (Virdi,1994; Thussu, 1995; Saini and Ananad, 1996; GSI, 2000). A map of the Sirsa -Hissar area showing part of the DSR configuration is given in Fig.6. It is traversed by NESW and NW-SE buried faults, with no visible reflection on the surface. However, the Ghagghar river tends to 


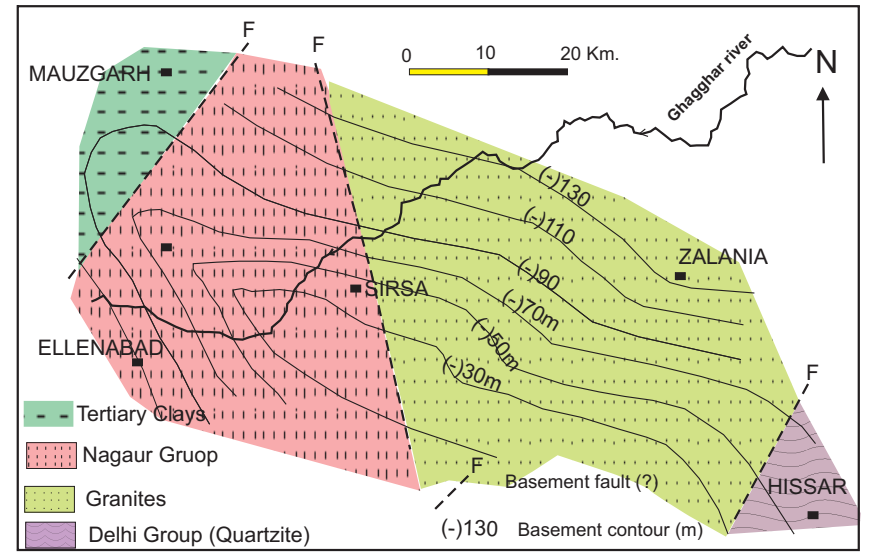

Figure 6. Basement contour map of Sirsa -Hissar area, Haryana showing a part of the NW-SE trending Delhi-Surgodha Ridge (Below sea level) with lithology and structure (Based on the bore hole data of CGWB, GSI and field observations).

become wider and shallower downstream of the NNW-SSE fault passing through Sirsa (Fig.3. C, D; Saini and Anand, 1996). Indirect evidence of tectonics can also be seen in the anomalous behavior of Ghagghar river in form of off-settings, one north of Tohana, between Phulad and Akalgarh (Patiala district) where southwest flowing Ghagghar suddenly assumes a straight northwesterly course for about $5 \mathrm{~km}$ and then again becomes southwesterly. This right lateral shift appears to be due to a subsurface NW-SE strike-slip fault (?) with no surface trace. The left out part of Ghagghar downstream of Makror Sahib occurs as a highly meandering, dry, incipient channel of about $7 \mathrm{~km}$ length, as Joya nalla. A second off-setting occurs NW of Fatehabad along the Haryana-Punjab boarder, between Ahlapur and Sardulewala. It also represents a right-lateral shift.

The DSR is perpendicular to the NNE-SSW Delhi Fold Belt associated with the Mahendragarh-Dehradun fault on its west flank (Srivastava and Somayajulu 1996; Shukla et al., 2007). Intersection of these two features in Sonepat-Rohtak-Bahadurgarh area is frequently reactivated and is manifested by earthquakes the focal mechanism of which indicate compressional tectonics in the ambience (Shukla et al., 2007; Prakash and Shrivastava, 2012). Twelve earthquakes varying between 2.2-5.0 magnitude on Richter scale have been reported in this small area since August, 2016 (India Meteorological Department,. www.imd.gov.in) which itself is indicative of an active tectonic regime below the plains. Ground tilt induced by the active faults can have long term bearing on the landscape and drainage evolution. Such shifts have potential to detach tributaries from the high order river and starve it of its perennial supply. Therefore, the recognition of tectonic activity and its influence on drainage needs to be explored to better understand the selective drying up of a major river i.e. the Saraswati between two major rivers.

\section{Summary}

1. There is enough data to say that the Saraswati / GhaggharHakara river flowed in NW Indian plains and gradually dried up between 15 and $4.3 \mathrm{ka}$. The river course, however, kept on flooding and aggrading to the upland level by silt-clay sediments. The entire course of river is yet to be precisely mapped and validated.
2. There is strong possibility of a subsidiary channel of the Sutlej connecting the Saraswati in the piedmont zone of PunjabHaryana plains supplying perennial water. The connection appears to have been lost around 11.6 ka ago. This inferred connection needs to be validated by the startigraphic and chronological studies in relation with the surrounding upland.

3. Linkage of the Yamuna River with the Saraswati River through its westerly flow appears to had been severed by $18 \mathrm{ka}$. This palaeocourse was subsequently encroached upon by aeolian deposits during 18-12 ka.

4. Drying of the Saraswati River, generally attributed to deterioration of Indian Summer Monsoon, needs to be evaluated in light of the active tectonics of Himalaya and basement structures of the foreland to explain why only the Saraswati River dried without affecting the nearby the Sutlej and the Yamuna rivers.

5. View that the Saraswati river was the lifeline of Indus civilization may not be tenable in light of new results suggesting considerable drying up of Saraswati river during 15-5 ka much before the advent of mature Indus civilization 4.5-4.4 ka BP.

6. Our understanding of the activities of active faults in outer Himalayan belts and in the basement below the Quaternary plains is poor especially in relation to the drainage reorganization and landscape evolution of the Saraswati palaeocourse belt and catchment. Investigations are needed to develop this data base.

7. Validating the course of buried Saraswati river in the dynamic Quaternary plains of northwestern India from Himalaya exit to its sinking in Arabian sea requires a thematic ground mapping of thousands of sq $\mathrm{km}$ area along its path complemented by sedimentological, chorological and geochemical framework

\section{Acknowledgements}

The paper benefited from discussions with Shri S.A.I Mujtaba, Director (Retd.) Geological Survey of India. The field work in part was supported by the Ministry of Earth Sciences grant on “A 100ka glaciations-deglaciation history of Ladakh: its comparison with Sutlej valley and signatures in the alluvial plains of NW India (MoES/PAMC/ H\&C/51/2013-PC-II to NCP. We are thankful to an anonymous reviver whose suggestions helped us in improving this manuscript.

\section{References}

Anand, V.K. and Kazim, K., 1992. Geological cum geomorphological mapping of Haryana and adjoining area based on Landsat Data interpretation, Geological Survey of India Report. Field Season 1989-90, Operation: Punjab, Haryana and Himachal Pradesh, Faridabad..

Bakliwal, P. C. and Grover, A. K., 1998. Signature and migration of Saraswati river in Thar desert, Western India. Rec. Geol. Surv. India, v 116, pp 77-86.

Berkelhammer, M., Sinha, A., Stott, L., Cheng, H., Pausata, F.S. and Yoshimura, K., 2012. An abrupt shift in the Indian monsoon 4000 years ago. Geophys. Monogr. Ser, v. 198.

Bhadra, B.K., Gupta, A.K. and Sharma, J.R., 2009. Saraswati Nadi in Haryana and its linkage with the Vedic Saraswati River- 
integrated study based on satellite images and ground based information. Journal of the Geological Society of India, v. 73, pp.273-288.

Bhatia, S.B. and Singh, N., 1988. Middle Holocene palaeoclimatic and palaeoenvironmental events in southern Haryana. Bulletin Indian National Science Academy, v. 54, pp.574-584.

Chakrabarti, D.K. and Saini, S., 2009. The problem of the Sarasvati river and notes on the archaeological geography of Haryana and Indian Panjab. Aryan Books International.

Clift, P. D., and Plumb, R.A., 2008. The Asian monsoon: causes, historyand effects. Cambridge: Cambridge University Press.

Clift, P.D., Carter, A., Giosan, L., Durcan, J., Duller, G.A., Macklin, M.G., Alizai, A., Tabrez, A.R., Danish, M., VanLaningham, S. and Fuller, D.Q., 2012. U-Pb zircon dating evidence for a Pleistocene Sarasvati River and capture of the Yamuna River. Geology, v. 40, pp.211-214.

Clift,P.D., Giosan,L., 2018. Holocene evolution of rivers, climate and human societies in the Indus basin. In water, Societies and technologies from the Past and Present (eds).Y.Zhuang, M.Altawed. DOI: 10.2307/jtv550c6p.8.

Dikshit, K.N., 2013. Origin of Early Harrapan cultures in the Saraswati valley. Recent Archeological evidence and Radiometric dates. Jour. Ind. Ocean Arch,v.9, 87-141

Dixit, Y., Hodell, D. A. and Petrie, C. A., 2014. Abrupt weakening of the summer monsoon in northwest India 4100 yr ago. Geology, v. 42, pp 339-342.

Dixit, Y., Hodell, D.A., Sinha, R. and Petrie, C.A., 2014. Abrupt weakening of the Indian summer monsoon at $8.2 \mathrm{kyr}$ BP. Earth and Planetary Science Letters, v. 391, pp.16-23.

Dixit, Y., Hodell,D., Giesche, A.,Tandon,S.K., Gázquez, F., Saini, H.S., Skinner, L.C., Mujtaba, S.A.I.,Pawar, V., Singh, R.N. andPetrie,C.A.,2018. Intensified summer monsoonand the urbanization of Indus Civilization in northwest India

Durcan, J.A., Thomas, D.S., Gupta, S., Pawar, V., Singh, R.N. and Petrie, C.A., 2017. Holocene landscape dynamics in the GhaggarHakra palaeochannel region at the northern edge of the Thar Desert, northwest India. Quaternary International.doi.org/ 10.1016/j.quant.2017.10.012.

Enzel, Y., Ely, L.L., Mishra, S., Ramesh, R., Amit, R., Lazar, B., Rajaguru, S.N., Baker, V.R. and Sandler, A., 1999. High-resolution Holocene environmental changes in the Thar Desert, northwestern India. Science, v. 284, pp.125-128.

Ghose, B., Kar, A. and Husain, Z., 1979. The lost courses of the Saraswati River in the Great Indian Desert: New evidence from landsat imagery. Geographical Journal,v. 145, pp.446-451.

Giosan, L., Clift, P.D., Macklin, M.G., Fuller, D.Q., Constantinescu, S., Durcan, J.A., Stevens, T., Duller, G.A., Tabrez, A.R., Gangal, K. and Adhikari, R., 2012. Fluvial landscapes of the Harappan civilization. Proceedings of the National Academy of Sciences, v. 109(26), pp.E1688-E1694.

Giosan,L., Orsi,W.D., Coolen,M., Wuchter,C., Dunlea1,A.G., Thirumalai,K., Munoz,S.E., Clift,P.D., Donnelly,J.P., Galy, V. and Fuller,D.Q., 2018. Neoglacial Climate Anomalies and the HarappanMetamorphosis. Climate of the. Past Discussions. https:/ /doi.org/10.5194/cp-2018-37

Geological Survey of India, 2000. Siesmotectonic Atlas of India and its Environment, Government of India.

Gupta, A.K., Sharma, J.R., Sreenivasan, G. and Srivastava, K.S., 2004. New findings on the course of River Sarasvati. Journal of the Indian Society of Remote Sensing, v. 32, pp.1-24.

Kalyanaraman, S., Sarasvati River, Goddess and civilization. In Vedic Sarasvati (Eds Radhakrishna, B. P. and Merh, S. S.), 1999.Memoir Geological Society of India, No. 42, pp. 25-34.

Kalyanaraman, S. ed., 2008. Vedic River Sarasvati and Hindu
Civilization. Aryan Books International.

Kar, A., 1999.A hitherto unknown palaeodrainage system from the radar imagery of southeastern Thar Desert and its significance. Memoir Geological Society of India, v.42, pp.229-235.

Kenoyer,J.M., 1998. Ancient cities of Indus valley civilization. Oxford university press.

Kenoyer, J.M., 2008. Collaborative archaeological research in Pakistan and India. SAA Archaeological Record, 8(3), pp.12-20.

Khonde, N.N., Maurya, D.M. and Chamyal, L.S., 2017. Late Pleistocene-Holocene clay mineral record from the Great Rann of Kachchh basin, Western India: Implications for palaeoenvironments and sediment sources. Quaternary International, v.443, pp.86-98.

Kshetrimayum, K.S. and Bajpai, V.N., 2011. Establishment of missing stream link between the Markanda river and the Vedic Saraswati river in Haryana, India-geoelectrical resistivity approach. Current science, v. 100, pp.1719-1724.

Kumar, G., 2005.Geology of Uttar Pradesh \& Uttaranchal. Geological Society of India, Bangalore. 384p, ISBN No: 81-85867-66-6

Kumar, S., Wesnousky, S.G., Rockwell, T.K., Briggs, R.W., Thakur, V.K. and Jayangondaperumal, R., 2005. The Himalayan Frontal Thrust of India is not blind. Journal of Geophysical Research.

Kumar, R., Kumar, H., Rawat, V. and Joshi, R., 2012. Delineation of lithostratigraphic units of Siwalik Belt in North-western Haryana and adjoining parts of Punjab and Himachal Pradesh. Gelogical Survey of India Report, Northern Region, Faridabad. F.S. 201012.

Lal, B.B., 2002. The Sarasvati flows on: the continuity of Indian culture. Aryan Books International.

Lal, R., Saini, H.S., Pant, N.C. and Mujtaba, S.A.I, (2018) Tectonics induced switching of provenance during the Late Quaternary aggradation of the Indus River Valley, Ladakh, India, Geoscience Frontiers (2018), ttps://doi.org/10.1016/j.gsf.2017.12.016

Lawler, A., 2008. Indus Collapse: The End or the Beginning of an Asian Culture? Science, v. 320 .pp1281-1283.

Madella, M. and Fuller, D.Q., 2006. Palaeoecology and the Harappan Civilization of South Asia: a reconsideration. Quaternary Science Reviews, v. 25, pp.1283-1301.

Maemoku, H., Shitaoka, Y., Nagatomo, T. and Yagi, H., 2012. Geomorphological constraints on the Ghaggar River regime during the Mature Harappan period. Climates, Landscapes Civilizations, Geophysical Monograph Series 198, pp.97-106.

Mehdi, S.M., Pant, N.C., Saini, H.S., Mujtaba, S.A.I. and Pande, P., 2016. Identification of palaeochannel configuration in the Saraswati River basin in parts of Haryana and Rajasthan, India, through digital remote sensing and GIS. Episodes, v. 39, pp.2938.

Malik, J.N., Nakata, T., Philip, G. and Virdi, N.S., 2003. Preliminary observations from a trench near Chandigarh, NW Himalaya and their bearing on active faulting. Current Science, v. 85, pp.17931798.

Mughal, M.R., 1997. Ancient Cholistan: Archaeology and architecture. Ferozsons. Rawalpindi, Karchi, Lahore. Ferozsons.

Nakata, T., 1972. Geomorphic history and crustal movement of the foot-hills of the Himalayas. Science Report Tohoku University. 7th series (Geography), v. 22, pp.39-177.

Nakata, T., 1989. Active faults of the Himalaya of India and Nepal. Geological Society of America Special Paper, v. 232, pp.243264.

Naruse, T., 1974. Sand dunes in the Punjab Plains, in Geographical Field Research in Northwestern India: A Progress Monograph, edited by H. Ishida, pp.122-128, Dep. of Geogr.,Hiroshima Univ., Hiroshima, Japan.

Naruse, T., 1985. Aeolian geomorphology of the Punjab Plains and 
the north Indian desert. Ann. Arid Zone, v. 24, pp.267-280.

Oldham, C.F., 1893. Art. III.-The Saraswati and the Lost River of the Indian Desert. Journal of the Royal Asiatic Society, v. 25, pp.49-76.

Oldham, R.D., 1886. On probably changes in the geography of the Punjab and its rivers: an historico-geographical study. Journal of Asiatic Society of Bengal v.55, pp 322e343.

Orengo, H.A. and Petrie, C.A., 2017. Large-scale, multi-temporal remote sensing of palaeo-river networks: a case study from northwest India and its implications for the Indus Civilization. Remote Sensing, v. 9, p.735.

Prakash, R. and Shrivastava, J.P., 2012. A review of the seismicity and seismotectonics of Delhi and adjoining areas. Journal of the Geological Society of India, v. 79, pp.603-617.

Petrie, C.A., 2013. South Asia. In Oxford handbook of cities in history. Peter Clark, ed. Pp. 139-173. Oxford: Oxford University Press.

Possehl, G.L., 2002. The Indus civilization: a contemporary perspective. Rowman. Altamira.

Radhakrishna, B.P. and Merh, S.S. (eds.), 1999. Vedic Sarasvati: evolutionary history of a lost river of northwestern India. MemoirGeological Society of India. No. 42, p 329.

Rajawat, A.S., Verma, P.K., Nayak, S., Rajawat, A.S., Verma, P.K. and Nayak, S., 2003. Reconstruction of palaeodrainage network in northwest India: retrospect and prospects of remote sensing based studies. Proceedings-Indian National Science Academy,Part A, v. 69, pp.217-230.

Roy, A.B. and Jakhar, S.R., 2001. Late Quaternary drainage disorganization, and migration and extinction of the Vedic Saraswati. Current Science-Bangalore, v. 81, pp.1188-1195.

Rydh, H., 1958. Rang Mahal- Swedish Archeoilogical Expedition to India 1952-1954. C W K Publishers Lund (Sweden). The Anew Book company, Bombay India.

Sahai, B., 1999. Unraveling of the 'lost'Vedic Sarasvati. MemoirsGeological Society of India, pp.121-142.

Saini, H.S. and Anand, V.K., 1996. Lithostratigraphic framework and sedimentological evolution of the Quaternary deposits of northwestern Haryana. Geol. Surv. India, Sp .Pub. v. 21(2), pp 227-231.

Visesa Prakasana-Bharatiya Bhuvaijñanika Sarveksana, v.21, pp.227231.

Saini, H. S., Tandon, S. K., Mujtaba. S. A. I, Pant,N.C., 2005. Lake deposits of the northeastern margin of Thar Desert: Holocene (?) Palaeoclimatic implications. Current Science, Vol. 88, No. 12, pp.1994-200.1

Saini, H.S. and Mujtaba, S.A.I., 2002. Geoenvironmental appraisal of Firozpur district, Haryana. . Geological Survey of India Report, Northern Region, Chandigarh. F.S. 2000-01.

Saini, H.S. and Mujtaba, S.A.I.,2004.Evaluation of Water-logging Conditions in Northwestern Parts of Haryana-Causes and Remedies with special reference Lithologic, Hydrologic and Geomorphologic Parameters. Unpub. GSI , Northern Region Report F.S. 2001-02 \&2002-03.

Saini, H.S., Tandon, S.K., Mujtaba, S.A.I., Pant, N.C. and Khorana, R.K., 2009. Reconstruction of buried channel-floodplain systems of the northwestern Haryana Plains. Current Science, v. 97. pp 1634-1643.

Saini, H. and Mujtaba, S., 2010. Luminescence dating of the sediments from a buried channel loop in Fatehabad area, Haryana: insight into Vedic Saraswati River and its environment. Geochronometria, v. 37, pp.29-35.

Saini, H.S. and Mujtaba, S.A.I., 2012. Depositional history and palaeoclimatic variations at the northeastern fringe of Thar Desert, Haryana Plains, India. Quaternary International, v. 250, pp.3748.
Sarkar, A., Mukherjee,A.D., Bera,M.C., Das,B., Juyal,N., Morthekai,P., Deshpande., R.D., Shinde, V.S. and Rao., L.S., 2016. Oxygen isotope in archaeological bioapatites from India: Implications to climate change and decline of Bronze Age Harappan civilization. Scientific Report. 6, 26555; doi: 10.1038/ srep26555.

Sharma, S.C., 1974. The description of rivers in the Rig Veda. Geogr. Obs, v. 10, pp. 79-85.

Sharma, D.P., Sharma, M. and Pandey, K., 2008. The lost Saraswati Civilization. Bharatiya Kala Prakashan.

Shukla, A.K., Prakash, R., Singh, R.K., Mishra, P.S. and Bhatnagar, A.K., 2007. Seismotectonic implications of Delhi region through fault plane solutions of some recent earthquakes. Current Science, pp.1848-1853.

Shukla, M., Kumar, R. and Mujtaba S.A.I., 2014. Report on the late Quaternary stratigraphy and and geomorphic evolution of the alluvial plains along the Ghagghar river. Geological Survey of Indias Report , Faridabad , F.S. 2012-13, 2013-14,

Singh, A., Thomsen, K.J., Sinha, R., Buylaert, J.P., Carter, A., Mark, D.F., Mason, P.J., Densmore, A.L., Murray, A.S., Jain, M. and Paul, D., 2017. Counter-intuitive influence of Himalayan river morphodynamics on Indus Civilization urban settlements. Nature Communications, v. 8 (I), pp.1617.

Sinha, R., Yadav, G.S., Gupta, S., Singh, A. and Lahiri, S.K. 2013, Geo-electric resistivity evidence for subsurface palaeochannel systems adjacent to Harappan sites in northwest India. Quaternary International, v.308, pp66-75.

Sood, R.K. and Sahai, B., 1983. Hydrographic changes in northwestern India. Man and Environment, v. 7, pp.166-89.

Srivastava, L.S. and Somayajulu, J.G., 1966. The seismicity of area around Delhi. Proc. III symposiam on Earthquake Engg., Univ. of Roorkee, pp.417-422.

Srtvastava, G.S., Singh, I.B. and Kulshrestha, A.K., 2006. Late quaternary geomorphic evolution of Yamuna-Sutlej interfluve: Significance of terminal fan. Journal of the Indian Society of Remote Sensing, v. 34, pp.123.

Srivastava, G.S., Singh, I.B. and Kulshrestha, A.K., 2014. Geomorphic and Tectonic features of Punjab-Haryana Plain as identified from digital elevation model and surface profiles. Himalayan Geology, v. 35, pp.97-109.Srivastava, V, Mukal,M., Barnes,J.B., 2016. Main Frontal thrust deformation and topographic growth of the Mohand Range, northwest Himalaya. Jou. Structural geology, v.,93,pp.138-148.

Staubwasser, M., Sirocko, F., Grootes, P.M. and Segl, M., 2003. Climate change at the $4.2 \mathrm{ka}$ BP termination of the Indus valley civilization and Holocene south Asian monsoon variability. Geophysical Research Letters, v. 30.,p 1425..

Staubwasser, M. and Weiss, H., 2006. Holocene climate and cultural evolution in late prehistoric-early historic West Asia. Quaternary Research, v. 66, pp.372-387.

Stein, A., 1942. A survey of ancient sites along the” lost” Sarasvati River. The Geographical Journal, v. 99, pp.173-182.

Thakur, V.C., 2013. Active tectonics of Himalayan Frontal Fault system. Int. jour Earth Sciences, v.102(7), pp 1791-1807.

Thussu, J.L., 1995. Quaternary stratigraphy and sedimentation of the Indo-Gangetic plains, Haryana, Journal of the Geological Society of India, v. 46 , p533-543.

Thussu, J.L., 1999. Role of tectonics in drainage migration in PunjabHaryana plains in recent times, In: Memoirs-Geological Society of India, 46,pp 205-218.

Thussu, J.L., 2006. Geology of Haryana and Delhi, Geological Society of India, Publications, ISBN No: 81-85867-75-5.

Tripathi, J. K., Bock, B., Rajamani, V. and Eisenhauer, A., 2004. Is river Ghaggar, Saraswati? Geochemical constraints. Current 
Science, 87, 1141-115.

Valdiya, K.S., 1996. Saraswati that disappeared, Resonance, v.1(5), pp.19-28

Valdiya, K.S., 2002.Saraswati: The river that disappeared, Universities Press, Hyderabad.

Valdiya, K.S., 2003. Reactivation of Himalayan frontal fault: implications. Current Science, pp.1031-1040

Valdiya, K.S., 2013. The River Saraswati was a Himalayan-born river. Current Science, v. 104, pp. 42-54.

Valdiya, K.S., 2016. Prehistoric River Saraswati: Geological Appraisal and Social Aspects, Springer, $136 \mathrm{p}$.

Virdi, N.S., 1994. The floor of Tertiary basin of northwest India controls of basement highs and Palaeotopography on the basin evolution. Himalayn Geology, v. 15, pp 231-244.

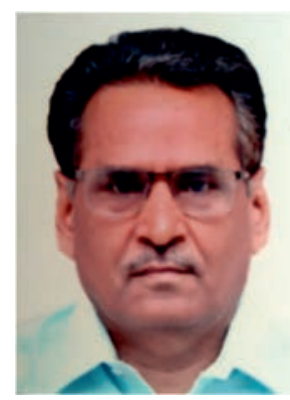

H.S.Saini passed his M.Sc Geology from Kurukshetra University. He has Ph.D in Quaternary Geology and geomorphology from Garhwal University, Srinagar. Before joining Geological Survey of India in 1979 he briefly worked as Lecturer and geohydrologist. During his 34 years in GSI, he mapped Quaternary terrains in NW Himalaya and Indo-Gangetic plains and set up its first OSL dating lab where he dated about 400 samples from diverse terrains. Presently he is teaching geology and working on paleoclimate and palaeodrainge of the NW Indian plains. He has over 50 publications and 20 technical reports.

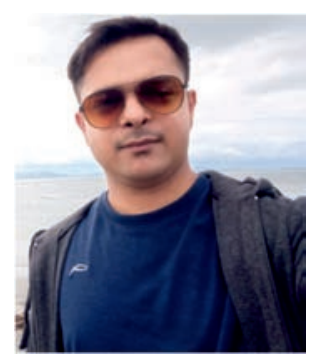

Apurva Alok, is a research scholar in University of Delhi working on the topic related to drainage evolution and reorganization in North Western India and in context of the Harappan Civilization and climate changes.
Wadia, D.N., 1978. Geology of India. Tata-Mc-Graw Hill Publishing Co., New Delhi pp1-54, 364-389.

Wilhelmy, H., 1999. The ancient river valley on the eastern border of the Indus Plain and the Sarasvati problem, Memoirs-Geological Society of India, 42, pp95-112.

Wright RP, Bryson R, Schuldenrein J., 2008. Water supply and history: Harappa and the Beasregional surveys. Antiquity,v. 82, pp 37-48.

Yashpal, Sahai, B., Sood, R.K. and Agarwal, D.P.,1980, Remote sensing of the lost Saraswati river, Proceedings and Indian Academy of Science (Earth \& Planetary Science), v.89 , pp.317337.

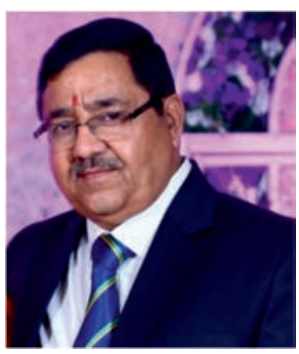

Naresh Chandra Pant works on microdomain characterization of geological material including the instrumentation associated with it. He has applied the technique to wide range of terrains including in Indian shield, East Antarctica and in the Himalaya. He is involved in planning of Indian Antarctic program nationally and with Scientific Committee on Antarctic Research (SCAR) internationally (2011-till date). He is a National Mineral awardee and fellow of Electron Microscope Society of India. He is the Deputy Chief Officer of SCAR currently. His PhD is from Mohan Lal Sukhadia University Udaipur in 1990 was the first doctoral thesis out of Indian Scientific Expeditions to Antarctica. He has over 90 research publications and three edited books. 